\title{
THE EFFICACY OF A TRACKING-EDIBLE ZINC PHOSPHIDE/MOLASSES GEL DELIVERY SYSTEM FOR CONTROLLING ROOF RATS COMPARED WITH A TRADITIONAL METHOD
}

\author{
SOLIMAN, SOHAIL ${ }^{1}$, A. M. K. SOBEIHA ${ }^{2}$ \\ and FATMA M. EL-GOHARY ${ }^{3}$
}

1. Department of Zoology, Faculty of Science, Ain Shams University, Abbasiya, Cairo11566, Egypt

2. Department of Plant Protection, Faculty of Agriculture, Ain Sahms University, Shobra Al-Kheima, Cairo

3. Plant Protection Research Institute, ARC, Dokki, Giza

(Manuscript received 30 March 2016)

\begin{abstract}
$\mathrm{T}$ he present study was carried out as an attempt to overcome bait shyness developed by rats when they ingest sub-lethal doses of rodenticides. It depends on incorporating a rodenticide with a gel contaminant. Contaminated rodents would then ingest the toxicant during grooming and die. The efficacy of a tracking-edible zinc phosphide/molasses gel delivery system was tested through non-choice and free-choice laboratory feeding tests. In non-choice tests, the results indicated that the consumption of plain molasses gel equals $6.6 \%$ of the average individual body weight, while the consumption of the toxicant/gel bait equals $7.5 \%$ of that weight. The average daily amount of zinc phosphide ingested, in the form of toxicant/gel bait, was $68.4 \mathrm{mg} /$ a rat. Rat mortality was 75\% over 2 days. In freechoice tests, the average daily consumption of plain molasses gel was $48.7 \%$ of that of crushed maize, and its acceptability was $32.9 \%$. The average daily consumption of the toxicant/gel bait was $56 \%$ that of crushed maize. The daily mount of zinc phosphide ingested by individual rats was $21 \mathrm{mg} /$ individual rat. This amount was sufficient to kill $50 \%$ of tested caged rats. The acceptability of the gel/ toxicant bait was $36.2 \%$. The average daily consumption of $0.5 \%$ zinc phosphide/crushed maize bait was lower than the average daily consumption of plain crushed maize. The acceptability and mortality were $19.3 \%$ and $33.3 \%$, respectively. The results of the present study indicate that the acceptability, against plain crushed maize, of the toxicant/gel was about twice that of the toxicant/crushed maize and that the mortality among rats exposed to the toxicant/gel bait was higher than that among rats exposed to toxicant/crushed maize bait.
\end{abstract}

\section{INTRODUCTION}

The traditional methods of the control of roof rats and other commensal rodents include the use of the acute poison zinc phosphide, which has been used since the 1940 's, and is presently still being used. Extensive laboratory and field studies have been conducted on its effect on roof rats and other commensal rodents (Eisemann et 
al., 2003). One of the problems associated with the use of this poison, and other acute poisons, is that rodent pests frequently developed bait shyness when they consume sublethal doses of such poisons. To overcome this problem, rodents were contaminated with a zinc phosphide formulation which was then ingested when they groomed their fur (Soliman, 1989). Grooming behavior might, thus, be used to deliver toxicants for crop protection (Reidinger and Mason, 1986). The behavior and the physiological basis of groomíng have been investigated by various authors (Colbern et al., 1978; Dunn et al., 1979; Geyer and Kornet, 1982; Cohen and Price, 1979; Mason et al., 1985 and Reidinger and Mason, 1986). Reidenger and Mason (1983) referred to the physiological basis of grooming in rodents. They indicated that grooming an aversive tastant from the fur was associated with increased blood levels of corticosteroids which are believed to stimulate grooming in rodents. Thus grooming results in the perception of the aversive tastant, and perception of the aversive tastant results in more grooming and so on. Mason et al. (1982) earlier indicated that taste aversion can be observed during hetero-grooming of a cage mate but not during autogrooming or self-grooming.

Non-choice and free-choice feeding tests were carried out in the laboratory to evaluate the acceptability of plain molasses gel and toxicant/gel formulation. The daily amounts of the gel/toxicant formulation consumed by individual rats were compared to the amounts of crushed maize/toxicant formulation, as traditional bait, consumed by these rats. The efficacy of a tracking-edible zinc phosphide/molasses gel delivery system was tested.

\section{MATERIALS AND METHODS}

\section{Test animals}

A total of 30 roof rats, Rattus rattus, were used in the present study. Rats were housed in wire cages $(50 \times 30 \times 20 \mathrm{~cm})$, and observed for at least 2 weeks before treatment. Food and water were provided to rats ad libitum.

\section{Preparation of molasses gel}

The method used by Soliman (1988) for preparing of molasses gel tests used by some modifications. The gel prepared consisted of wheat flour, margarine, and molasses mixed together in the following proportions by parts: $3: 1: 6$. The gel was prepared according to the following steps:

Flour was carefully mixed with margarine in an operineum for one minute. Molasses was then added and mixed carefully for 3 minutes.

The prepared molasses gel has the following characters:

1 - It is prepared from locally available and inexpensive ingredients.

2- Tacky for about 60 days.

3- Not having repellent qualities. 


\section{The delivery system and the preparation of toxicant/gel formulation}

A plastic tube, $20 \mathrm{~cm}$ long and $5.5 \mathrm{~cm}$ inner diameter was used for providing either the molasses gel or the toxicant/gel formulation to caged test rats. In the present study, zinc phosphide was used in a concentration of $0.5 \%$ in molasses gel (i.e., $5 \mathrm{mg}$ zinc phosphide/g gel). The $L D_{50}$ of zinc phosphide in case of roof rats is $21.3 \mathrm{mg} / \mathrm{kg}$ body weight (Hilton, and Robin, 1972).

\section{Testing the efficacy of toxicant/gel delivery system using non-choice feeding tests}

A known amount $(30 \mathrm{~g})$ of each of plain molasses gel and poison/gel bait was evenly applied to the inner surface of each of the plastic tubes using a spatula, and one tube was presented to each caged rat. Eight rats were tested with each of the plain molasses gel and $0.5 \%$ zinc phosphide/molasses gel formulation, in $24 \mathrm{hr}$ nonchoice tests. Water was provided ad libitum for rats. The daily amounts of each of the plain molasses gel and zinc phosphide/molasses gel bait removed by individual rats, and the occurrence of rat mortalities were recorded.

\section{Testing the efficacy of toxicant/gel delivery system using free-choice}

feeding tests: comparison between molasses gel and crushed maize formulations

Free choice feeding tests were carried out according to the following steps:

1. A known amount (30g) of crushed maize (a), placed in a dish, and a known amount $(30 \mathrm{~g})$ of plain molasses gel (b), evenly applied to the inner surface of a plastic tube, were provided daily to each of 8 caged rats for 4 days. Water was provided to rats ad libitum.

2. A known amount (30g) of $0.5 \%$ zinc phosphide/molasses gel (c) and a known amount $(30 \mathrm{~g})$ of crushed maize (a), placed in a dish, were presented daily to each of 8 caged roof rats for 2 days.

3. A known amount (30 g) of each of crushed maize (a), and $0.5 \%$ zinc phosphide/crushed maize (d) were daily presented to 6 roof rats for 2 days.

The daily amounts of each of (a), (b), (c), and (d) removed by individual rats were estimated. The acceptability and mortality of rats were calculated. Rats were noticed for seven days after treatment.

The acceptability, by rats, of any bait formulation or food material (1) relative to another such material (2) in non-choice or free-choice feeding tests was calculated according to the following equation (Mason et al., 1989):

$$
\text { Acceptability of "1" (\%) }=\frac{\text { Average daily consumption of "1" }(\mathrm{g})}{\text { Average total daily consumption of "1+2" (g) }} \times 100
$$




\section{RESULTS}

\section{Non-choice test:}

Results of the application of both plain molasses gel and $0.5 \%$ zinc phosphide/molasses gel formulation to caged rats showed that the average daily consumptions of molasses gel (control) and $0.5 \%$ zinc phosphide/molasses gel formulation were $12.8 \mathrm{~g}$ and $13.7 \mathrm{~g}$, respectively (Table 1 ). The difference between these amounts is statistically insignificant. These amounts represent $90 \%$ of actually recorded ones. It is supposed that $10 \%$ of the gel was lost during testing. The average daily consumption of toxic molasses gel is thus $107 \%$ of the consumed amount of plain molasses gel (control). The daily consumptions of plain molasses gel and toxicant/ gel formulation were $6.6 \%$ and $7.5 \%$ of the average individual body weight.

Rat mortality was $75 \%$ over a period of 2 days after the application of poison/gel formulation. The average amount of zinc phosphide ingested by individual rats was thus $68.4 \mathrm{mg} /$ individual. This amount of zinc phosphide equals $17.7 \mathrm{LD}_{50}$, expressed as $\mathrm{mg} / \mathrm{kg}$ body weight. The acceptability of the gel/toxicant formulation was $51.7 \%$ (Table 1).

\section{Free-choice test}

Results of the application of molasses gel and crushed maize to caged rats in free choice tests showed that the average daily consumption of molasses gel was $49.1 \%$ of that of crushed maize (Table 2). It should be noticed that the amount of consumed molasses gel is considered to be $90 \%$ of its actually recorded amount. The average daily amounts consumed by individual rats were $12.1 \mathrm{~g}$ and $5.9 \mathrm{~g}$ for crushed maize and plain molasses gel, respectively. The acceptability of molasses gel, relative to crushed maize, was $32.7 \%$. The average daily consumption of crushed maize was higher than that of molasses gel.

Results of the application of $0.5 \%$ zinc phosphide/molasses gel formulation to caged roof rats in free-choice tests indicated that the average daily consumption of the toxicant/gel formulation was $56.7 \%$ that of crushed maize (Table 3 ). The average daily amounts consumed by individual rats were $7.5 \mathrm{~g}$ and $4.2 \mathrm{~g}$ for crushed maize and the toxicant/gel formulation, respectively. It should be noticed that the amount of consumed toxicant/gel formulation is considered to be $90 \%$ of its actually removed amount. It contains an average amount of zinc phosphide that equals 5.6 $\mathrm{LD}_{50}$ expressed as $\mathrm{mg} / \mathrm{kg}$ body weight. This amount was sufficient to kill $50 \%$ of caged test rats. The acceptability of the gel/toxicant formulation, relative to crushed maize, was $36.2 \%$. 
Results of the application of $0.5 \%$ zinc phosphide/crushed maize formulation to caged roof rats in free-choice test are presented in. showed that The average consumed daily amounts of $0.5 \%$ zinc phosphide/crushed maize and plain crushed maize were $0.8 \mathrm{~g}$ and $3.4 \mathrm{~g}$, respectively (Table 4 ). The average daily consumption of $0.5 \%$ zinc phosphide/crushed maize formulation by rats was thus $24 \%$ the average daily consumption of plain crushed maize. The acceptability and mortality were $19.3 \%$ and $33.3 \%$, respectively. The average daily consumption of crushed maize was significantly higher than that of crushed maize/zinc phosphide formulation in free choice test.

The obtained results indicated that the acceptability of $0.5 \%$ zinc phosphide/molasses gel formulation was about twice that of $0.5 \%$ zinc phosphide/crushed maize baits. The acceptabilities of the toxicant/gel formulation and toxicant/crushed maize baits were $36.2 \%$ and $19.3 \%$, respectively.

The mortality among rats treated with toxicant/gel formulation was 1.5 times higher than that among rats treated with zinc phosphide/crushed maize baits. The mortalities were $50 \%$ and $33.3 \%$ among rats treated with toxicant/molasses gel formulation and $0.5 \%$ toxicant/crushed maize baits, respectively.

\section{DISCUSSION}

One approach to overcome bait shyness in rodents, or the presence of an alternative food, is to contaminate them with a toxic formulation which is then ingested during grooming (Sanchez, 1977; Poché et al., 1979; Fellows, 1980). The use of contact poison/gel formulation is preferred in many situations because it is generally safer than dusts since it is less mobile and spillages are more easily cleared. The placement of a gel is more precise and its active ingredient is often less concentrated than that of dusts (Meehan, 1984).

Early laboratory and field trials were done for presenting rodenticides to rats through their grooming behavior. Poché et al. (1979) applied zinc phosphide/grease formulations to the bamboo sticks in the entrances of the burrows of the lesser bandicoot rat, Bandicota bengalensis in Bangladesh, but the results were not encouraging. Automotive grease/zinc phosphide and used motor oil/zinc phosphide formulations were also applied to banana leaves and to tiles and put along the runways of Rattus rattus mindanensis in rice paddies in the Philippines (Sanchez, 1977; Fieldler, 1979, 1983). Morris et al. (1983) developed a brodifenacoum containing wick device and evaluated its use for the control of commensal house mice. Reidinger, Jr. (1985) invented a method and apparatus for automatically dispensing a measured amount of a rodent control liquid onto the dorsal fur of rodents. Soliman (1988) developed simple devices for contaminating rats and mice with toxicant/gel 
formulations, and tested both molasses gel and petroleum jelly as potential gels for contaminating albino rats and mice. He found that molasses gel was more readily removed by these rodents than petroleum jelly.

Zinc phosphide, as an acute poison, is used here for the preparation of a toxicant/gel formulation. This rodenticide has been used for several decades for controlling rodents and other vertebrate pests. This is because this poison has low risk of secondary poisoning, and is not environmentally persistent (Anonymous, 2011). According to the same author, it is planned that the use of this poison in both paste and solid cereal baits will be extended to control rodents and other vertebrate pests in New Zealand.

The results of the present study indicate that the use of zinc phosphide/molasses gel formulation has resulted in higher mortalities among roof rats than among rats treated with zinc phosphide/crushed maize baits.

In non-choice tests, the average daily consumption of toxic molasses gel was $107 \%$ of the consumed amount of plain molasses gel, and the daily consumption of each of plain molasses gel and toxicant/gel formulation were $6.6 \%$ and $7.5 \%$ of the average individual body weight. These ratios are considered as high ones since rats normally consume a quantity of food materials that equals $10 \%$ of their body weight (Meehan, 1984). This means that plain molasses gel as well as the toxicant/gel formulation are readily accepted and removed by caged roof rats.

In free-choice tests, the average daily consumption of crushed maize was higher than that of molasses gel, and the acceptability of molasses gel, relative to crushed maize, was $32.9 \%$. These results are comparable to the results of Soliman (1989) who indicated that wild Norway rats, Rattus norvegicus, preferred wheat grains than molasses gel in simulated grain store studies. The mortalities among these rats, which did not show signs of active removal of the toxicant/gel formulation, were $46 \%$. Preliminary studies conducted by Soliman and Daoud (2004) on the use of a zinc phosphide/molasses gel delivery system in the control of the roof rat, $R$. rattus gave promising results.

A zinc phosphide/gel formulation was also tested for the control of other vertebrate pests (possums) in New Zealand. The results indicated that majority of possums tested have ingested the poison while grooming the toxic gel, and died (Blackie et al., 2016).

The tubes used here for delivering the toxic gel to roof rats proved to be successful in this respect. They were listed among the bait stations currently used in the control of rodents (O'Connor and Eason, 2000). 
Table 1. Results of the application of plain molasses gel and $0.5 \%$ zinc phosphide/molasses gel formulation to caged roof rats in non-choice feeding tests. Average is followed by \pm S.D., and range in (parentheses).

\begin{tabular}{|c|c|c|c|c|c|c|c|c|c|}
\hline & & & Average daily cc & umption (g) & & & & \multicolumn{2}{|c|}{$\begin{array}{c}\text { Mortality } \\
\text { (\%) }\end{array}$} \\
\hline Applied food & $\begin{array}{c}\text { No. of } \\
\text { individuals }\end{array}$ & $\begin{array}{c}\text { Average body } \\
\text { weight (BW) (g) }\end{array}$ & Total & $\begin{array}{c}90 \% \\
\text { of } \\
\text { consumed } \\
\text { gel }\end{array}$ & $\begin{array}{l}\text { amount of } \\
\text { ingested zinc } \\
\text { phosphide } \\
\text { (mg) }\end{array}$ & $\begin{array}{l}\text { ingested zinc } \\
\text { phosphide in } \\
\text { relation to BW } \\
\quad(\mathrm{mg} / \mathrm{kg})\end{array}$ & $\begin{array}{c}\text { Acceptability } \\
\text { (\%) }\end{array}$ & No. & $\%$ \\
\hline Plain molasses gel & 8 & $\begin{array}{c}192.5 \pm 44.64 \\
(120-240)\end{array}$ & $\begin{array}{c}14.21 \pm 6.35 \\
(2.4-20)^{\mathrm{ns}}\end{array}$ & 12.79 & & & & & \\
\hline $\begin{array}{c}0.5 \% \text { zinc phosphide molasses } \\
\text { gel formulation }\end{array}$ & 8 & $\begin{array}{c}181.25 \pm 34.41 \\
(130-250)\end{array}$ & $\begin{array}{c}15.20 \pm 6.87 \\
(5.0-20)^{\mathrm{ns}}\end{array}$ & 13.68 & 68.40 & 377.38 & 51.68 & 6 & 75 \\
\hline
\end{tabular}

The vertical columns marked with the same litters are not significantly different by SAS (2006). 
Table 2. Results of the application of plain molasses gel and plain crushed maize to caged roof rats in free-choice feeding tests. Average is followed by \pm S. D., and range in (parentheses).

\begin{tabular}{|c|c|c|c|c|c|c|}
\hline \multirow[b]{2}{*}{$\begin{array}{l}\text { No. of } \\
\text { individuals }\end{array}$} & \multirow[b]{2}{*}{ Average body weight $(\mathrm{g})$} & \multirow{2}{*}{$\begin{array}{l}\text { Average daily consumption of } \\
\text { plain crushed maize (g) } \\
\text { (1) }\end{array}$} & \multicolumn{2}{|c|}{$\begin{array}{l}\text { Average daily consumption of } \\
\text { Plain molasses gel }(\mathrm{g})\end{array}$} & \multirow[b]{2}{*}{$\begin{array}{c}\text { Accept-ability } \\
(\%)\end{array}$} & \multirow[b]{2}{*}{$\begin{array}{c}\text { Molasses gel as } \% \text { of crushed } \\
\text { maize }(2 / 1 \%)\end{array}$} \\
\hline & & & Total & $\begin{array}{c}90 \% \text { of consumed } \\
\text { molasses gel }\end{array}$ & & \\
\hline 8 & $\begin{array}{c}203.75 \pm 25.04 \\
(170-240)\end{array}$ & $\begin{array}{c}12.06 \pm 6.19 \mathrm{~A} \\
(7.92-26.86)\end{array}$ & $\begin{array}{l}6.58 \pm 2.52 \\
(3.77-9.99)\end{array}$ & $5.92 \mathrm{~B}$ & 32.93 & 49.10 \\
\hline
\end{tabular}

The vertical columns marked with the same litters are not significantly different by SAS (2006). 
Table 3. Results of the application of $0.5 \%$ zinc phosphide/molasses gel and plain crushed maize to caged roof rats in free-choice feeding tests. Average is followed by $\pm S$. D., and the range in (parentheses).

\begin{tabular}{|c|c|c|c|c|c|c|c|c|c|c|c|c|}
\hline \multirow[b]{2}{*}{$\begin{array}{l}\text { No. of } \\
\text { individuals. }\end{array}$} & \multirow[b]{2}{*}{$\begin{array}{l}\text { Mean body } \\
\text { weight (BW) } \\
\text { (g). }\end{array}$} & \multirow{2}{*}{$\begin{array}{l}\text { Average daily } \\
\text { consumption } \\
\text { of plain crushed } \\
\text { maize (g) } \\
\text { (1) }\end{array}$} & \multicolumn{2}{|c|}{$\begin{array}{l}\text { Average daily consumption of zinc } \\
\text { phosphide/molasses gel }\end{array}$} & \multirow[b]{2}{*}{$\begin{array}{l}\text { Average amount } \\
\text { of daily ingested } \\
\text { zinc phosphide } \\
\text { (mg) }\end{array}$} & \multicolumn{3}{|c|}{$\begin{array}{c}\text { Average daily ingested zinc } \\
\text { phosphide in relation to } B W \\
\text { and } L D_{50}\end{array}$} & \multicolumn{3}{|c|}{ Mortalities } & \multirow[b]{2}{*}{$\begin{array}{l}\text { Toxic bait as } \\
\text { percent of } \\
\text { crushed maize } \\
(2 / 1 \%)\end{array}$} \\
\hline & & & Total & $\begin{array}{c}90 \% \text { of } \\
\text { consumption } \\
\text { (2) }\end{array}$ & & $\mathrm{mg} / \mathrm{kg}$ & $\mathrm{LD}_{50}$ & $\begin{array}{l}\text { Expressed } \\
\text { as } \mathrm{LD}_{50}\end{array}$ & $\begin{array}{l}\text { Acceptability } \\
(\%)\end{array}$ & No. & $(\%)$ & \\
\hline 8 & $\begin{array}{c}177.5 \pm 34.54 \\
(130-230)\end{array}$ & $\begin{array}{l}7.48 \pm 5.67 \mathrm{~B} \\
(0.95-14.21)\end{array}$ & $\begin{array}{l}4.71 \pm 1.14 \\
(3.44-6.19)\end{array}$ & $4.24 \mathrm{CB}$ & 21.2 & 119.4 & 21.3 & 5.61 & 36.17 & 4 & 50 & 56.67 \\
\hline
\end{tabular}

The vertical columns marked with the same litters are not significantly different by SAS(2006). 
Table 4. Results of the application of plain crushed maize and $0.5 \%$ zinc phosphide/crushed maize bait to caged roof rats in a freechoice test. Average is followed by \pm S.D., and range (in parentheses).

\begin{tabular}{|c|c|c|c|c|c|c|}
\hline \multirow[b]{2}{*}{ No. } & \multirow[b]{2}{*}{$\begin{array}{l}\text { Mean body } \\
\text { weight }(g)\end{array}$} & \multicolumn{2}{|c|}{$\begin{array}{l}\text { Average individual daily } \\
\text { consumption } \quad(\mathrm{g})\end{array}$} & \multirow[b]{2}{*}{$\begin{array}{c}\text { Acceptability } \\
\text { (\%) }\end{array}$} & \multicolumn{2}{|c|}{ Mortalities } \\
\hline & & $\begin{array}{c}\text { Untreated } \\
\text { crushed maize }\end{array}$ & $\begin{array}{l}\text { Zinc phosphide/ } \\
\text { crushed maize }\end{array}$ & & No. & $\%$ \\
\hline 6 & $\begin{array}{c}188.33 \pm 37.64 \\
(140-240)\end{array}$ & $\begin{array}{c}3.42 \pm 2.88 C B \\
(0.02-6.69)\end{array}$ & $\begin{array}{l}0.82 \pm 0.54 C \\
(0.40-1.65)\end{array}$ & 19.34 & 2 & 33.33 \\
\hline
\end{tabular}




\section{REFERENCES}

1. Anonymous. 2011. Research and development highlights at the Centre for Wildlife Management and Conservation, January to December 2011-our platform for 2012. Lincoln University, New Zealand, 28 pp.

2. Blackie, H.; J. MacKay; B. Barrett; S. Inder; D. MacMorran; J. Bothwell; M. Clout and C. Eason. 2016. A novel device for controlling bushtail possum (Trichosurus vulpecula). New Zealand J. Ecol., 40 (1): 60-64.

3. Cohen, J. A. and E. O. Price. 1979. Grooming in the Norway rat: displacement activity or boundary shift. Behav. Neur. Biol., 26: 177-188

4. Colbern, D. L., R. L. Isaacson, E. J. Green and W. H. Gispen. 1978. Repeated intraventicular injections of ACTH 1-24: The effects of home or novel environments on excessive grooming. Behav. Biol., 23: 281-387.

5. Dunne, A. G., E. J. Green and R. L. Isaason. 1979. Intracerebral adrenocorticotropic hormone mediates novelty-induced grooming in the rat. Science, 203: 281-283.

6. Eisemann, J. D., B. E. Petersen, K. A. Fagerstone. 2003. Efficacy of zinc phosphide for controllig Norway rats, roof rats, house mice, Peromyscus spp., Prairie dogs and ground squirrels: A literature review (1942-2000). Proc. 10th Wildl. Damage Mgmt. Conf. (K A. Fagerstone and G. W. Witmer, Eds.), pp. 335349.

7. Fellows, D. P. 1980. Tracking grease roller application test. Progress Report, Work Unit 925. 07, Evaluation of New Rodenticides and Formulations, U.S. Fish and Wildlife service, Wildlife Damage Reserch Station, Hilo, Hawaii, Progress Report, Work Unit 925. 07, 1- 6 pp.

8. Fiedler, L. 1979. Reducing rat damage to mature rice using zinc phosphide in motor oil. Denver Willdlife Research Center, Vertebrat Damage Control Research in Agriculture, Annual Report: 75-80.

9. Fiedler, L. 1983. Using rodenticide in tracking grease to control rats in rice. Ibid.: 75-80.

10. Geyer, L. D. and C. A. Kornet. 1982. Auto- and allogrooming in pine voles, Microtus pinetorum and meadow voles, Microtus pensy/vanicus. Physiol. Behav., 28 (3): 904-12,.

11. Hilton, H. R. and W. R. Robinson. 1972. Fate of zinc phosphide and phosphine in the soil-water envirionment. J. Agric. Food Chem., 20: 1209-1213.

12. Mason, J. R., L. A. Geyer and C. A. Kornet. 1982. Social context affects expression of conditioned taste aversion during grooming by pine voles: implications for animal damage control. Wildl. Damage Manage. Intern., Cent., 
for East. Pine and Meadow Vole Symposia. Unive. of Nebraska., Lincoln,pp. 110119

13. Mason, J. R., R. F. Reidinger and Y. Katz 1985. Flavor avoidance expressed in grooming by pine voles (Microtus pinetorum): importance of context and hormonal factors. Physiol. Behav., 35(6): 979-983,.

14. Mason, J. R., L. Avery, and D. L. Ots. 1989.Standard protocol for evaluation of repellent effectiveness with birds. Bird Section Res. No. 20, B, DWRC, pp. 1-20.

15. Meehan, A. P. 1984. Rat and Mice: their biology and control. The Rentokil Library. Printed in Great Britain by Brown Knigh \& Trusco Lad. pp3731

16. Morris, K. O., R. D. Proctor and D. E. Kaukeinen. 1983. Vertebrate Pest Control and Mangement Materials. $4^{\text {th }}$ Symp. Amer. Soc. for testing and materials, Philadelphia,165. $\mathrm{p}$

17. O'Connor, C. E. and C. T. Eason. 2000. Rodent baits and delivery systems for island protection. Science for Conservation 120, Department of Conservation, Wellington, New Zealand, 25 pp.

18. Poché, R. M., S. Parvin, T. M. Main and E. Haque. 1979. Studies with zinc phosphide on Bandicota bengalensis and Rattus rattus in Bangladesh. Banglad. J. Zool., 7 (2): 117-123.

19. Reidinger, Jr., R. F., 1985. Method and automated device for applying measured amounts of control liquieds to the dorsal fur of rodent pests. United State Patent, No. 4, 541- 199.

20. Reidinger, Jr., R. F. and J. R. Mason 1983. Exploitable characteristics of neophobia and food aversions for improvements in rodent and bird control. Vert. Pest Cont. Manage. Materials, 4th. Symp. ASTM STP 817, D.E. Kaukeinen, Ed., Amer. Soc. Testing and Materials, Philadelphia, pp. 20-39.

21. Reidinger, Jr., R. F. and J. R. Mason 1986. Effect of learned flavor avoidance on grooming behavior in rats. Physiol. Behav., 37 (6): 925-185.

22. Sanchez, F. 1977. Potential use of grease formulation to deliver oral toxicant to Rattus r. mindenensis. Denver Wildlife Research Center, Control of Verteprate Pests Annual Progress Report: p.30-31

23. Soliman, S. 1988. Developing a tracking-edible gel toxicant delivery system for control of Rattus norvegicus and Mus musculus. Proc. Egypt. Acad. Sci., 38: 179185.

24. Soliman, S. 1989. The use of a zinc phosphide/molasses gel and a brodifacoum/molasses gel delivery system for the control of Rattus norvegicus and Mus musculus. Bull. Zool. Soc. Egypt, 38: 179-185.

25. Soliman, S. and S. N. Daoud. 2004. A preliminary evaluation of the efficacy of a molasses gel/zinc phosphide delivery system for the control of the roof rat, Rattus rattus. Ann. Rev. Fac. Women Art. Sci. Edu. Ain Shams Univ., 23: 65-69. 


\title{
اختبار كفاءة خليط غذائى-عالث من جيلاثين العسل الأسود وفوسفيد الزنك فى

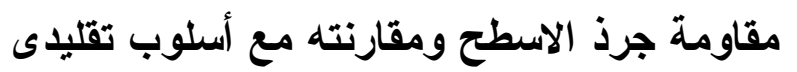

\author{
سهيل سليمان '، أمجد صبيحة ‘، فاطمة متولى '

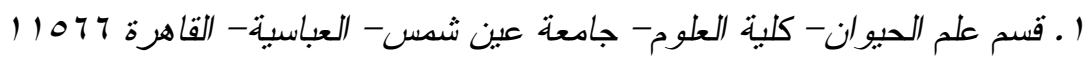 \\ r ـ قسم وقاية النبات- كلية الزراعة- جامعة عبن شمس- شبر ا الخبمة- القاهرة \\ r م ـعهز بحوث وقابة النباتات- مركز البحوث الزراعية- الدقى - الجيزة
}

أجريت هذه الدراسة كمحاولة للتغلب على مشكلة النفور عن الطعوم السامة بواسطة الجرذان بعد

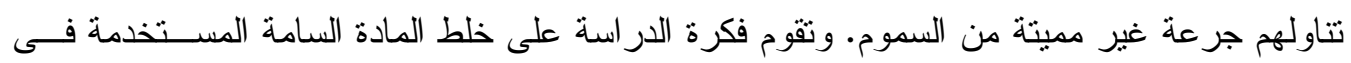

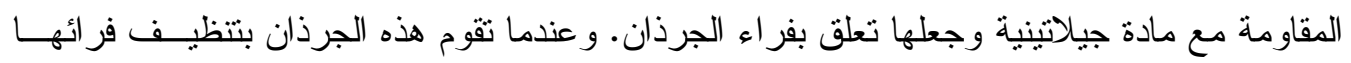

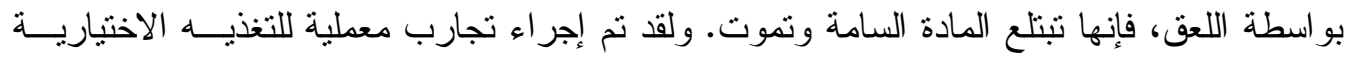
و القسرية لتقييم كفاءة الجيلاتين السام عندما يقدم للجرذان بواسطة جهاز بسيط، وتمت مقارنة كفــاءة ولهاء هذه الطريقة بطريقة تقليدية للمقاومة.

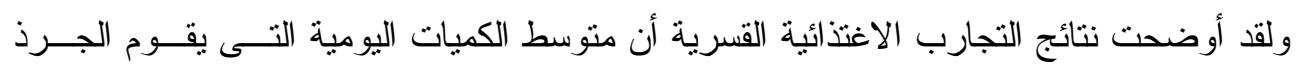

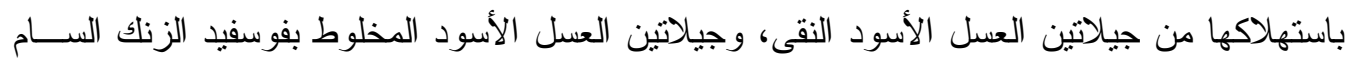

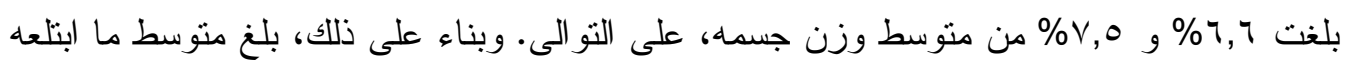

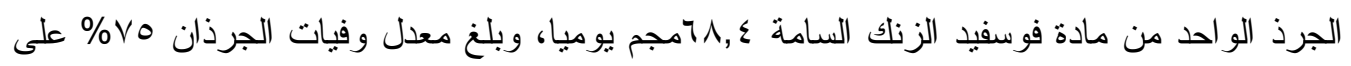
مدى يومين من ابتلاعها المادة السامة. ولقد أوضحت نتائج التجارب الاغتذائية الاختبارية أن منوسط الكميات اليومية من جيلاتين العسل دئل

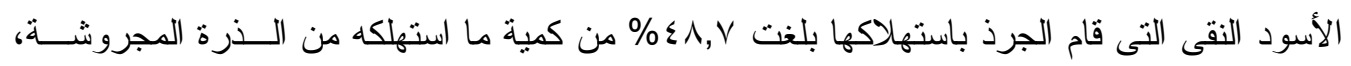

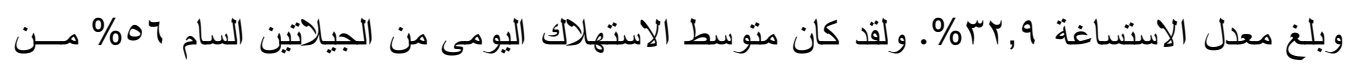

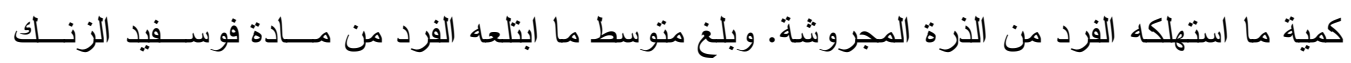

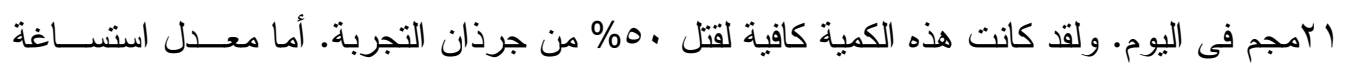

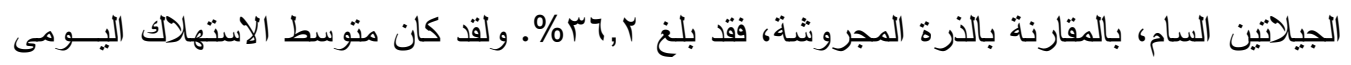

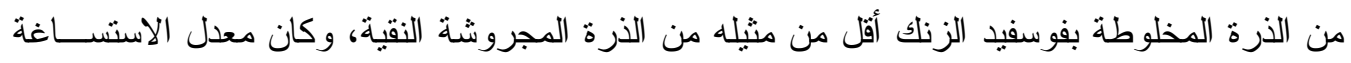

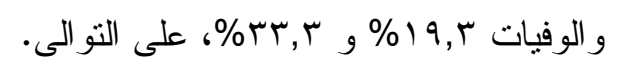

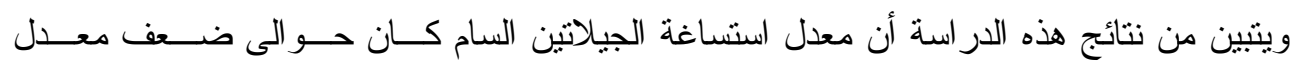

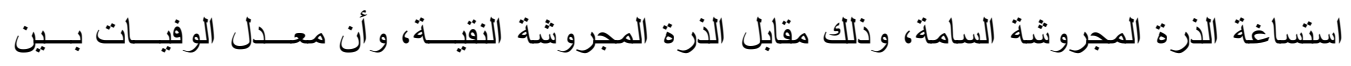

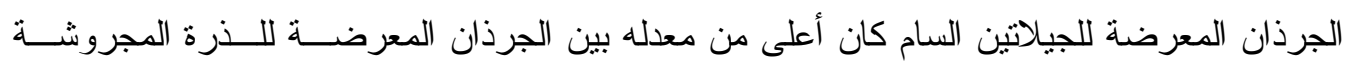

